\title{
The Early Colonial Circum-Caribbean: Affected and Infected by Colonialism and Disease
}

Kennedy-Jude Providence

University of Toronto

FAS Biology and Health and Disease/Caribbean Studies

\section{A B S T R A C T}

Oftentimes when thinking about the plantocracy, slavery and the Circum-Caribbean region, the first thing that comes to mind is the suffering endured by millions of Indigenous populations, genocide and forced African migrants, enslaved, and tortured for the singular benefit of European enrichment. Any historical thought process is usually followed by a celebration of the region's nutrient rich soil, an ideal climate for successful agriculture. However, there are further aspects that are not often given due weight in consideration, including the numerous subtle and intricately intertwined ways Colonialism impacted the region scientifically, specifically through disease and immunological degradation. This research paper seeks to highlight and consider the multiple ways in which the region was not only affected but also infected by disease and Colonialism.

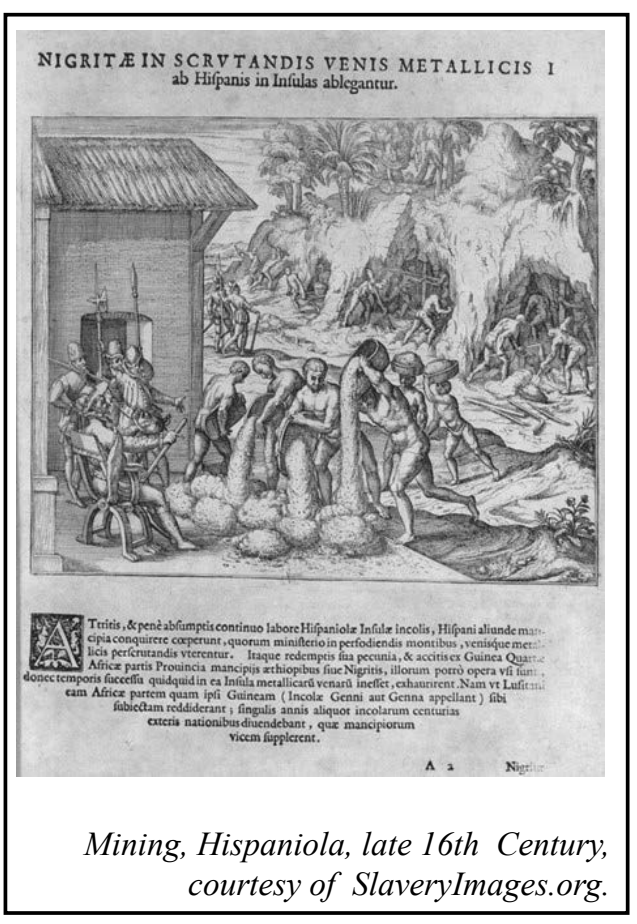

Keywords: Colonialism, Immunology, Disease, Caribbean, Slavery.

\section{B I O}

Kennedy Providence is a 4th year Biology, and Health and Disease double major, also pursuing a minor in Caribbean Studies at the University of Toronto. The diverse, shared history of the West Indies has been an interest of hers for as long as she can remember.

Caribbean Studies Students'Union, Canada - https://jps.library.utoronto.ca/index.php/cquilt/ 
While there are numerous ways in which one may consider the colonial project in the Circum-Caribbean, it may be argued that its histo-environmental effects are often given insufficient consideration. The suffering and genocide endured by millions of Indigenous peoples and the forced migration, torture, and enslavement of Africans had a detrimental impact on the physical and psycho-social environment of the region. Collectively, through the mono-cultivation of the king crop- sugarcane, the mining of precious metals, and the introduction of novel disease, European powers slowly but most steadfastly, drained the unadulterated treasury that was the Caribbean basin to support the rapid proliferation of their emerging, mercantilist societies. Focusing on the Early colonial Caribbean, this paper seeks to consider the ways in which immunological degradation was used to benefit and further the colonial project in the 17th and 18th Century.

Indigenous peoples faced an even greater threat than armed invasion - disease (Montenegro and Stephens 2006, 186). In order to wholly comprehend the reason for the devastating impact disease had on the Indigenous Populations of the region, we must first briefly discuss and have a basic understanding of the Human Immune system. Scientifically speaking, immunological memory against disease is acquired once one is exposed to a pathogen - a disease causing organism (Balloux and van Dorp 2017, 1). Following this initial encounter, the body deploys its immediate, or innate immune system to not only fight the infection but produce antibodies which invoke immunological 'memory' to 'remember' this virus in the
Indigenous Caribbean inhabitants' immune systems, unaccustomed to alien diseases, viral and bacterial infection exploded into the leading cause of death of these once virile populations. As a result, disease ultimately posed a greater threat to survival than armed invasion (Montenegro and Stephens 2006, 1861).

Soon after 1492, European sailors inadvertently introduced diseases, such as smallpox and measles, mumps, whooping cough, influenza, chicken pox, and typhus to the Americas. In the first century after the initial Columbian exchange, approximately $93 \%$ of the Caribbean's Indigenous population died a massive demographic collapse that scholars often mainly attribute to the foreign bacterial and viral diseases introduced by Europeans (Montenegro and Stephens 2006, 1861). However, this infers that regardless of colonial modes of subjugation, Indigenous populations were too weak to ward off novel infection. This is despite the fact that "Indigenous peoples in [the Circum-Caribbean] had perhaps one of the most sophisticated and diverse Indigenous health systems in the world" (Montenegro and Stephens 2006, 1865). The experienced medicinal and herbal proficiency of Indigenous peoples translated into a wisdom that offered a multitude of natural remedies for pre-Colombian illnesses. This was due in part to the fact that these populations were naturally, a migratory people. The organic movement of the Indigenous population, whether stimulated by amicable or hostile terms, supported the exchange of medicinal practices and herbal knowledge during regional encounters. 
Considering this broad and sophisticated medical knowledge base however, questions arise from the inability to rehabilitate their dying population from these novel ailments plaguing the region. Such a question, however, places insufficient consideration on the unjust, demanding working conditions, that created harsh and inhumane physical environments but also inhibited sufficient recovery time for the infected and ill. Under the stress of excessive labour requirements "the viruses suffered by the Indigenous populations [left] victims who escape, killed, or as weak as a kitten for weeks." (McNeill 2012, 35)

Despite the sometimes ambient, sometimes encircling biological genocide, the Europeans never lost sight of their goal of resource exploitation. Columbus and his men first noted the richness of the soil, in their recounts of the islands protection by a vast, barrier-like wall of foliage. However, upon meeting the people who inhabited the land, the colonizers' focus shifted quickly to the brilliant gold and silver pieces adorning the autochthonous population, the latter oblivious to the European attraction and value placed on their ornaments. Applying forced privilege, power and supremacy, the invaders established control over the islands and mining operations were initiated; with native populations made to toil underground, endure barbaric working conditions, and extract precious metals for the financial gain of Europe.
As a result, this research posits that through these working conditions, European invasion altered the region's socio-environmental history by diverting the natural course of science away from the acquisition of immunological memory and the subsequent maturation and development of immune systems resulting in extinction. The Indigenous populations were denied the opportunity to develop immunity on their own terms and denied biological knowledge of newly introduced euro-diseases which itself shaped the direction of the scientific history of indigenous peoples.

While the Spaniards came to the New World in search of the proverbial "el dorado", imagined to be overflowing abundantly, the realization that this resource was in fact quite scarce and difficult to find and extract meant they shifted focus at the end of the 17th century to establishing an agrarian-based economic structure. Of all the cultivations, sugar cane flourished in the Tropical-Marine Caribbean climate and emerged as providing the most wealth to the Empire. Notwithstanding the ease with which the unrefined fruitage grew, the success of refining the crop relied on two integral factors: cheap, readily available labour, and cheap, easily accessible fuel. The Indigenous population, having been grossly depleted by the year 1620, mainly because of disease, now on the verge of extinction, was rendered an insufficient and therefore, unusable source of cheap, forced labour, prompting European invading nations to begin exploring new options: Africans. 
As the British Colonial Empire gradually grew in power simultaneously with the increasing value of sugar, the declaration of ownership and seizure of various territories in the Caribbean increased British colonies. These invaders brought with them 'suitable' labour, that is, massive numbers of enslaved, African migrants. Again, science repeated itself as the introduction of multiple unfamiliar populations, invited disease, epidemic, and death, hence, brutal suffering to a mass number of people, African enslaved and European alike, owing to a lack of immunological memory. In the case of the African slaves, yellow fever (McNeill 2012,41 ) was one disease that accompanied their involuntary passage to the Caribbean, 'eager' to be released upon new, upcoming territories and hosts.

It is imperative to note that the climate of the region not only supported the intensive cultivation of crops, but also the reproduction and survival of insects that served as the vectors or 'vessels' for the transmission of diseases. Though the Aedes aegypti mosquito, the disease carrying agent for yellow fever, was not indigenous to the Caribbean, and arrived as a result of the European slave trade, these vectors occupied a specific niches that the plantation society coupled with the Tropical marine climate unintentionally nurtured. Unlike many mosquitoes, A. aegypti eggs require clean, unpolluted water to mature into larvae and pupae (McNeill 2012, 41). As we envision the containers used to store the gargantuan volumes of sugar produced, as well as the additional barrels kept in case of excesses of production, coupled with the climate's high levels of seasonal and intermittent rainfall, this stagnant, fresh water collected, would have provided optimum conditions for the rapid and prolific reproduction and survival of this vector.

What is interesting about the science of this disease and its successive, detrimental effect, is that it was not unfamiliar to the enslaved African population, as the mosquito is of African origin, however, the living conditions endured by the enslaved, facilitated the effortless and most vicious transmission of the disease. With mosquito-borne diseases, the cycle's efficiency depends chiefly on three things: the population densities of people and vectors; the feeding focus of the vector, that is, whether or not it bites only people or bites people among other mammals; and the longevity of the vector. With attention to the first, it is plausible that the growing slave population, in any given island or territory, would have provided the virus with a more than satisfactory availability of hosts for easy, widespread replication and infection. Perhaps, as well, the intimate, ultra-close and unhygienic physical spaces provided as accommodation of enslaved persons, facilitated constant contact and ultimately fostered an environment again, ideal for disease transmission. These highly influential factors led to the infection of a plethora of people, and when many people were ill at the same time. This increase the virulence of the disease. 
Planters, disgruntled by slave population reduction aka asset loss and impediments to support and sustain consistent production capacity, used the opportunity of disease to create racist, gendered stereotypes that bolstered the stability of the plantocracy. As scholars often note, "the plantation's wealth relied on its structure being by necessity racist" (McWatt 2019, 66). 17th and 18th-century observers often claimed that men were more vulnerable than women, although this characterization is tempered by a colonial mentality that saw vulnerability as a consequence of intemperance - a trait typically associated with males (Mcneill 2012, 35).

If we think about McNeill's statement, it is quite alarming because, in spite of the numbers of enslaved people that fell ill, including those that succumbed to their illness, many Europeans also contracted the disease and endured intolerable sufferings and death. Yet, I am not surprised with McNeill's statement for two reasons: First, though the Europeans placed the African enslaved at the bottom of their social strata, they expected this labour force to be able to withstand the most unbearable of conditions, while maintaining a submissive attitude. The high expectations set for these forced migrants were in stark contrast to the lowly treatment meted out by their masters. Second, the foundation of the plantocracy was built on racism and social divisions. The ease with which the European observers were able to make spurious claims - that the virus may affect more men than women, and by further offering some rationale for that vulnerability - though due to illness, was indicative of the Euro-defined traits of the "disobedient" African male, one of several racially-driven stereotypes about the enslaved population; indirectly referencing the white man's superior discipline, intelligence and apparently resistance to disease.

The living conditions and density of the slave population in the Caribbean resulted in a mass number of slaves becoming immunologically affiliated with viral infection. This is significant as the plantation depended on these labouring imports to fuel the economy, withstand, and supply the high demand for Caribbean sugar, and fund the planters, their families and Europe. With a large portion of the labour force dead or substantially "weak as kittens", this slowed production, and negatively impacted the financial bottom-line of the plantocracy. Regardless of this fact, planters seemingly found a way to achieve their ambitious goals, despite widespread illness and a weakened labour force. I propose that the planters, driven by insatiable appetites, would have imported more slaves at formidable cost to quickly replace the dead. It is possible and is not far-fetched that there was some degree of manipulation or misappropriation that monetized loss of property, yielding monetary compensation from England ergo, a revolving reimbursable fund for new, more people-property acquisitions. History tells us that planters often insured their slaves, so it is possible that, due to the oceanic separation between the Caribbean region and the continent, slave losses due to diseases may have been overstated, exacerbated then unjustifiably funded, for unaudited personal benefit. 
This is not a preposterous allegation, especially if we consider the Zong Massacre of 1781, an indescribably tragic incident which involved the premeditated death of 130 slaves due to the respective Europeans' attempts to claim insurance on their murdered bodies. Jeremy Krikler (2012) notes that many planters and slave traders' written accounts, note that slaves were hand-picked by surgeons aboard slave ships, ensuring health, strength, and youth, before purchase. Regardless of the medical 'clearance', disease was heralded as the leading cause of death on slave ships. We remember that illness was viewed as vulnerability, and vulnerability- intemperance, justifying slavers' decisions to throw infected African bodies overboard; to avoid the spread of infection to other slaves, and crew members, to conserve the limited resources and it may be argued, it was similarly used to also invoke fear in the newly purchased cargo. All this is to say, slave owners and traders were able, from time to time to 'justly' kill their slaves, subsequently reap the benefits of this dastardly practice, and defend any imminent claims.

No doubt, Colonialism shaped the development of scientific history and anomalies of the early Caribbean through its imposition of deadly, novel, and infectious diseases to an immunologically unprepared, and unsuspecting Indigenous population. However, more importantly this immunological degradation was used to benefit and further the colonial project in the 17th and 18th Century by a) reducing the Indigenous population's ability to leverage existing medical knowledge to combat diseases and b) linking colonially defined intemperance to vulnerability and infection to subjugate African slaves.

The effects of these infectious diseases on the 'pioneer'-to-enslaved Indigenous and enslaved African populations developed an agrarian based economy, and not only shaped the scientific history, but added to growing fields of scientific research and ultimately, the overarching history stemming from the theft and colonization of the Circum-Caribbean region. 


\section{Works Cited}

Burnard, Trevor, and Richard Follett. "Caribbean Slavery, British Anti-Slavery, And The Cultural Politics Of Venereal Disease.” The Historical Journal 55, no. 2 (2012): 427-51. https://doi.org/10.1017/s0018246x11000513.

Crosby, Alfred W. The Columbian Exchange: Biological and Cultural Consequences of 1492. Westport, CT: Praeger, 2003.

Krikler, Jeremy. "A Chain of Murder in the Slave Trade: A Wider Context of the Zong Massacre." International Review of Social History 57, no. 3 (2012): 393-415. https://doi.org/10.1017/s0020859012000491.

McNeill,John Robert. Mosquito Empires: Ecology and War in the Greater Caribbean, 1620-1914. New York: Cambridge University Press, 2010

McWatt, Tessa. Shame on Me: an Anatomy of Race and Belonging. Toronto: Random House Canada, 2020

Balloux, Francois, and Lucy van Dorp. "Q\&A: What are pathogens, and what have they done to and for us?." BMC biology vol. 15,1 91. 19 Oct. 2017, doi:10.1186/s12915-017-0433-z

Montenegro, Raul A, and Carolyn Stephens. "Indigenous Health in Latin America and the Caribbean." The Lancet 367, no. 9525 (2006): 1859-69. https://doi.org/10.1016/s0140-6736(06)68808-9. 